JURNAL JENDELA ILMU

Vol.1, No. 1, Juni 2020, hlm. 13-22

\title{
SUSTAINABILITAS PERENCANAAN PROGRAM BANTUAN BERAS SEJAHTERA BERDASARKAN ANALISIS MULTIDIMENTIONAL POVERTY INDEX DI KAMPUNG AIMO KABUPATEN SORONG
}

\author{
Aram Palilu, Frits Gerit John Rupilele \\ Universitas Victory Sorong \\ Email: arampalilu1015@gmail.com
}

\begin{abstract}
Abstrak
Kemiskinan merupakan momok yang menakutkan bagi semua orang dan ada semua di negara (baik negaranegara miskin, berkembang maupun maju). Untuk mengentaskan kemiskinan maka semua pemerintah yang ada di dunia berupaya keras melalui pembangunan atau pun program-program bantuan tertentu. Salah satu program yang dianggap primadona untuk mengentaskan kemiskinan di Indonesia adalah program bantuan Beras Sejahtera. Sehubungan dengan itu, maka untuk program bantuan tersebut dapat dilanjutkan atau tidak maka perlu ditinjau mengenai tingkat keberhasilannya. Jenis penelitian yang digunakan dalam mengumpulkan data adalah penelitian lapangan (survey) dan divariasi dengan wawancara. Metode yang digunakan dalam penelitian ini adalah kuantitatif. Jumlah populasi sebanyak 75 Kepala Keluarga (KK) dan sampel yang terambil sebanyak 30 KK, sedangkan untuk menganalisis data yang diperoleh adalah menggunakan Multidimentional Poverty Index $(M P I)$. Tujuan daripada penelitian ini adalah untuk mengetahui keberhasilan suatu program bantuan Beras Sejahtera dalam mengatasi kemiskinan multidimensional yang meliputi kemiskinan kesehatan, pendidikan dan standar hidup yang layak di Kampung Aimo. Berdasarkan hasil penelitian menunjukkan bahwa angka devrivative MPI adalah sebesar $\mathrm{c} \geq 3,41$. Hasil ini menunjukkan bahwa masyarakat miskin di Kampung Aimo setelah mendapat program bantuan beras sejahtera belum mengalami peningkatan kesejahteraan (miskin). Dengan demikian, maka program bantuan Rastra masih harus dilanjutkan dan perlu dikombinasikan dengan program-program bantuan yang lainnya (Kartu Sehat, Kartu Pintar, dan sejenisnya).

Kata kunci: program bantuan beras sejahtera, kemiskinan kesehatan, kemiskinan pendidikan, dan kemiskinan standar hidup.

\section{SUSTAINABILITAS PLANNING FOR RICE ASSISTANCE PROGRAMS BASED ON MULTIDIMENTIONAL ANALYSIS POVERTY INDEX AT THE VILLAGE OF AIMO SORONG DISTRICT}

\begin{abstract}
Poverty is a scary scourge for everyone and there are all in the country (both poor countries, developing and advancing). To alleviate poverty, all the governments in the world are working hard through development or specific aid programs. One of the programs that is considered as a program to alleviate poverty in Indonesia is the rice prosperous aid program. Therefore, for such assistance programs can be continued or not, it is necessary to review the level of success. The type of research used in collecting data is field research (survey) and is varied with interviews. The method used in this study is quantitative. The population number is 75 family head $(\mathrm{KK})$ and the samples were taken as many as $30 \mathrm{KK}$, while analyzing the data obtained is using the Multidimentional Poverty Index (MPI). The purpose of this research is to find out the success of the Rice Sejahtera Assistance Program in overcoming multidimensional poverty which includes health poverty, education and a decent standard of living in Aimo village. Based on the results of the study showed that the devrivative MPI number is $c \geq 3.41$. These results suggest that the poor people in the village of Aimo after getting the rice assistance Program have not experienced the improvement of welfare (poor). Thus, the Rastra help program still needs to be continued and needs to be combined with other assistance programs (healthy card, smart card, and the like).
\end{abstract}

Keywords: Rice aid Program, Poverty health Poverty education, and poverty of living standards.

\section{PENDAHULUAN}

Indonesia, saat ini telah menikmati pertumbuhan ekonomi yang stabil dan menunjukkan keuntungan substansial dalam indikator-indikator sosial dengan penurunan angka kemiskinan secara bertahap, baik di daerah 
perkotaan maupun pedesaan dan sekarang Indonesia telah masuk dalam klasifikasi negara berpenghasilan menengah rendah. Meskipun ada prestasi mengesankan seperti itu, ada sekitar 28,6 juta orang $(11,6 \%)$ dari seluruh rumah tangga yang masih hidup di bawah garis kemiskinan nasional yang telah ditetapkan yaitu yang berpenghasilan 1,25 USD per hari (BPS, 2012). Selain itu, sebagian besar penduduk (38\%) hidup di bawah 1,5 kali garis kemiskinan itu dan sangat rentan untuk jatuh miskin akibat guncangan/shock. Dalam tiga tahun terakhir, seperempat dari seluruh penduduk Indonesia telah berada dalam situasi kemiskinan, setidaknya sekali (ww.digilib.itb.ac.id).

Pemerintah pusat memiliki sejumlah program untuk menurunkan angka kemiskinan, antara lain Bantuan Langsung Sementara Masyarakat (BLSM), Bantuan Siswa Miskin (BSM), Beras untuk Rumah Tangga Miskin (Raskin), Program Keluarga Harapan (PKH), Program Nasional Pemberdayaan Masyarakat (PNPM), bantuan untuk usaha mikro, kecil, dan menengah (UMKM), dan program-program lainnya yang tersebar di sejumlah kementerian. Belum lagi, program-program penanggulangan kemiskinan di daerah baik pada level provinsi maupun kabupaten/kota (Hadna, 2016).

Dari berbagai program yang telah disebutkan diatas, maka salah satu program yang sangat populis dalam meningkatkan kesejahteraan masyarakat miskin adalah program bantuan beras sejahtera (Rastra). Rastra merupakan salah satu dari berbagai program-program pro rakyat yang diluncurkan oleh pemerintah Indonesia sebagai upaya percepatan penanggulangan kemiskinan. Melalui peraturan perundangan yang menjadi landasan Program Raskin, seperti UU No. 7 Tahun 1996 Tentang Pangan, Peraturan Pemerintah No. 68 Tahun 2002 Tentang Ketahanan Pangan, Peraturan Presiden RI No. 54 Tahun 2005 Tentang Tim Koordinasi Penanggulangan Kemiskinan. kemudian ditidaklanjuti dalam Peraturan Presiden Republik Indonesia Nomor 15 Tahun 2010 tentang Percepatan Penanggulangan Kemiskinan dan Instruksi Presiden Nomor 3 Tahun 2010 tentang Program Pembangunan yang Berkeadilan.

Sebuah program yang telah diimplemntasikan tentunya harus dengan ditopang pula oleh perencanaan yang handal. Perencanaan pembangunan, yang diwujudkan melalui implementasi pada akhirnya bertujuan untuk meningkatkan kesejahteraan masyarakat (social welfare). (ww.digilib.itb.ac.id) Kesejahteraan masyarakat sering direfleksikan dengan tingkat pendidikan (sosial), kesehatan dan pendapatan (ekonomi). Oleh karena itu, alat ukur kesejahteraan sangat dibutuhkan untuk menganalisis sejauhmana dampak dari sebuah kebijakan terhadap masyarakat dan bagaimana keberlangsungan program tersebut.

Berkaitan dengan itu, secara umum pemerintah telah menetapkan syarat-syarat bagi penerima program bantuan Rastra, meliputi: 1) luas lantai kurang dari $8 \mathrm{~m}^{2}$ per orang, 2) jenis lantai tanah/bamboo/kayu murahan, 3) dinding rumah bambu atau kayu berkualitas rendah/tembok tanpa diplester, 4) tidak memiliki fasilitas kamar mandi dan toilet, 5) penerangan bukan listrik, 6) sumber air minum bukan PDAM (Perusahaan Daerah Air Minum)/tidak terlindung sungai dan air hujan, 7) tidak memiliki kompor atau menggunakan arang/kayu bakar, 8) membeli daging maksimal 1 kali sepekan, 9) 1 tahun membeli 1 stel pakaian baru, 10) frekuensi makan satu/dua kali sehari, 11) tidak mampu berobat ke puskesmas/poliklinik, 12) lapangan pekerjaan buruh tani, buru bangunan dan lainnya dengan pendapatan di bawah Rp 600.000,per bulan, 13) pendidikan tertinggi kepala rumah tangga tidak sekolah/tidak tamat SD/tidak tamat sekolah, 14) tidak memiliki tabungan, barang yang mudah dijual nilainya tidak sampai Rp 500.000,(Sumber: Data Kelurahan Kampung Klamalu).

Diharapkan dengan adanya program Rastra tersebut, maka kesejahteraan masyarakat Kampung Aimo yang misikin akan meningkat kesejahteraannya, namun program bantuan yang ada belum menunjukkan hasil yang maksimal sesuai dengan tujuan daripada program tersebut. Oleh karena itu, program bantuan yang telah digelontorkan dalam rentang waktu yang cukup lama perlu dievaluasi tingkat keberhasilannnya. Berdasarkan evaluasi terhadap keberhasilan suatu program maka dapatlah disimpulkan apakah program tersebut dilanjutkan atau tidak. Bila program tersebut belum berhasil dengan baik, maka tentu dicari letak masalahnya (akar masalah) berada dimana.

Kenyataannya menunjukkan bahwa masyarakat (RTM) di Kampung Aimo tidak berbeda dengan kondisi yang dialami sebelum adanya program bantuan Rastra, dimana program bantuan Rastra selama ini belum memberikan manfaat yang diinginkan oleh pemerintah. Hal ini disebabkan, kemungkinan penyaluran Rastra tidak efektif dan persoalan masalah sosial budaya masyarakat untuk menerima bantuan tersebut, walaupun dengan harga yang sangat murah. Oleh karena itu, perlu suatu tindakan yang benar-benar untuk mencari letak permasalahan utamanya (akar masalah). Jika persoalan-persoaln tersebut tidak menjadi perhatian yang serius, maka program bantuan tersebut tidak akan pernah berhasil dalam meningkatkan kesejahteraan masyarakat, khususnya RTM di Kampung Aimo.

Berdasarkan permasalahan permasalahan di atas, maka peneliti tertarik untuk melakukan 
penelitian dengan tujuan memberikan solusi yang tepat terhadap kemiskinan yang ada di Kampung Aimo. Sehubungan dengan itu, maka peneliti merumuskan judul penelitian: "Sustainabilitas Perencanaan Program Bantuan Beras Sejahtera Berdasarkan Analisis Multidimentional Poverty Index Di Kampung Aimo Kabupaten Sorong Provinsi Papua Barat”.

\section{TINJAUAN PUSTAKA}

\subsection{Kebijakan Publik}

Kebijakan publik yang dipahami sebagai kebijakan yang dibuat oleh badanbadan pemerintah dan para aktor politik yang bertujuan untuk menyelesaikan masalah publik merupakan sesuatu yang krusial untuk dipelajari dengan alasan: Pertama, untuk melihat sejauhmana isi kebijakan publik mampu memuat nilai-nilai dan kepentingan publik khususnya kelompok sasaran. Kedua, untuk mengkritisi proses formulasi kebijakan publik yang menyangkut: (a) apakah kebijakan tersebut ditetapkan secara demokratis, transparan, dan akuntabel; dan (b) bagaimana peran para aktor dan stakeholders dalam formulasi kebijakan. ketiga, mengidentifikasi apa dampak dari suatu kebijakan publik bagi individu, komunitas, dan masyarakat, serta pemerintah (Subarsono, 2009).

Keberhasilan suatu program akan ditentukan oleh hubungan dari tiga aspek, yakni jenis program, beneficiaries (penerima program), dan organisasi pelaksana program (Korten, 1988). Terkait dengan upaya atau pengentasan kemiskinan maka salah satu langkah yang ditempuh adalah program beras sejahteran (Rastra). Upaya ini sejalan dengan UUD 1945 menyebutkan bahwa penduduk miskin (fakir miskin) dan anak-anak terlantar dipelihara oleh negara.

Jenis kebijakan yang dimaksudkan disini adalah yang dibuat oleh pembuat kebijakan, yaitu kebijakan/program bantuan beras sejahtera yang berupa komoditas atau beras dengan harga yang dapat dijangkau oleh daya beli masyarakat yang miskin. Dengan demikian, tujuan dari program ini agar masyarakat miskin dapat terpenuhi kebutuhan mendasar.
Organisasi pelaksana kebijakan, pemerintah pusat melalui jajaran secara berjenjang khususnya Dinas Kesejahteraan Sosial sebagai penyalur beras sejahtera. Agar program batuan beras sejahtera ini berhasil sesuai dengan tujuan yang dinginkan maka penyalurannya harus benar-benar yang layak untuk menerima (masyarakat miskin yang tidak mempunyai pendapatan tetap dan mencukupi).

Berhubungan dengan hal tersebut, suatu usaha yang dilakukan untuk mengentaskan kemiskinan diperlukan suatu perencanaan program yang terukur berdasarkan hasil analisis yang terukur pula. Secara sederhana, usaha pembangunan yang dilakukan untuk mengatasi kesenjangan sosial dan ekonomi membutuhkan sebuah perencanaan yang akurat (Widodo, 2006). Apapun yang akan dilakukan oleh manusia yang rasional tidak pernah lepas dari suatu kegiatan perencanaan, melalui perencanaan program bantuan yang tepat merupakan suatu langka yang mudah untuk mengentaskan kemiskinan. Konsep kemiskinan merupakan suatu konsep yang multidimensional sehingga konsep kemiskinan tidak mudah untuk dipahami (Widodo, 2006). Karena itu, untuk memahami kemiskinan dan sekaligus untuk mengatasi kemiskinan tersebut perlu suatu perencanaan program bantuan yang matang dan terukur berdasarkan hasil analisis yang terukur pula.

\subsection{Kemiskinan Multidimensional (Multidimentional Poverty Index/MPI)}

Pada umumnya kemiskinan yang dihadapi dewasa ini adalah kemiskinan multidimensional, khususnya yang terdapat di Negara-negar Sedang Berkembang (miskin). Kemiskinan multidimensional ini, telah membentuk suatu "Lingkaran Setan Kemiskinan" (Vicious Circle of Poverty) yang diakibatkan oleh oleh beberapa faktor penentu, seperti yang tertera pada Gambar 2.1 berikut: 
Gambar: 2.1 Model/bagan Lingkaran Setan Kemiskinan

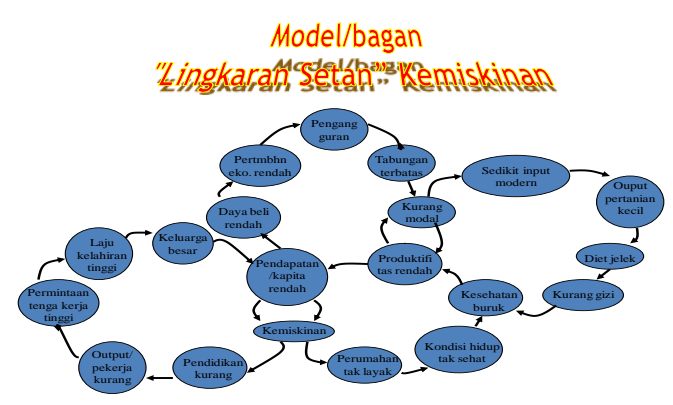

Model ini diadopsi dari: Triarko Nurlambang

Berdasarkan model tersebut, dapat dijelaskan bahwa kemiskinan yang ada sangat kompleks dan rumit untuk mencari solusi yang tepat untuk memutuskan mata rantai kemiskinan menjadi virtous circle of wealth (lingkaran kebajikan) untuk kemakmuran. Mata rantai lingkaran setan kemiskinan tersebut, dapat disederhanakan (dipadatkan) melalui hanya dapat diputuskan melalui suatu gerakan mengentaskan kemiskinan, salah satu diantaranya adalah program Raskin.

Berbagai batas pemenuhan kebutuhan minimum mengacu pada rekomendasi Widya Karya Nasional dan Gizi pada tahun 1978yang meliputi: Pertama, yaitu nilai rupiah dari pengeluaran untuk makanan yang menghasilkan energi 2.100 kilo kalori per orang setiap harinya. Sedangkan kebutuhan non pangan mencakup pengeluaran untuk perumahan, penerangan, bahan bakar, pakaian, pendidikan, kesehatan, transportasi, barang barang tahan lama serta barang dan jasa esensial lainnya; Kedua, Rumusan kemiskinan menurut Friedmann (1992) sebagai minimnya kebutuhan dasar sebagaimana yang dirumuskan dalam konferensi ILO tahun 1976. Kebutuhan dasar menurut konferensi itu dirumuskan sebagai berikut : (1) Kebutuhan minimum dari suatu keluarga akan konsumsi privat (pangan, sandang, papan dan sebagainya); (2) Pelayanan esensial atas konsumsi kolektif yang disediakan oleh dan untuk komunitas pada umumnya (air minum sehat, sanitasi, tenaga listrik, angkutan umum, dan fasilitas kesehatan dan pendidikan); (3) Partisipasi masyarakat dalam pembuatan keputusan yang mempengaruhi mereka ; (4) Terpenuhinya tingkat absolut kebutuhan dasar dalam kerangka kerja yang lebih luas dari hak-hak dasar manusia; (5) Penciptaan lapangan kerja (employment) baik sebagai alat maupun tujuan dari strategi kebutuhan dasar; Ketiga, The Depth of Proverty, yang menggambarkan dalamnya kemiskinan di suatu wilayah yang diukur dengan Indeks Jarak Kemiskinan (Poverty Gap Index); Keempat, The severity of Poverty yang diukur dengan Indeks Keparahan Kemiskinan (distributionally Sensitive Index). Indeks ini pada prinsipnya mengukur jarak yang memisahkan antara orang miskin dari garis kemiskinan, mengukur ketimpangan penduduk miskin atau penyebaran pengeluaran diantara penduduk miskin, maupun digunakan untuk mengetahui intensitas kemiskinan. Kelima, Indeks Kemiskinan Multidimensional (Multidimensional Poverty Index/MPI) yang meliputi tiga dimensi dan sepuluh indikator (variabel) yaitu: 1) dimensi kesehatan, terdiri dari 2 indikator; 2) dimensi pendidikan, terdiri dari 2 indikator; dan 3) dimensi standar hidup, terdiri dari 6 indikator.

Secara konseptual maka indeks kemiskinan multidimensional dapat digambarkan pada gambar 2.2 sebagai berikut:

Gambar 2.2 Model/Konseptual Kemiskinan Multidimensional

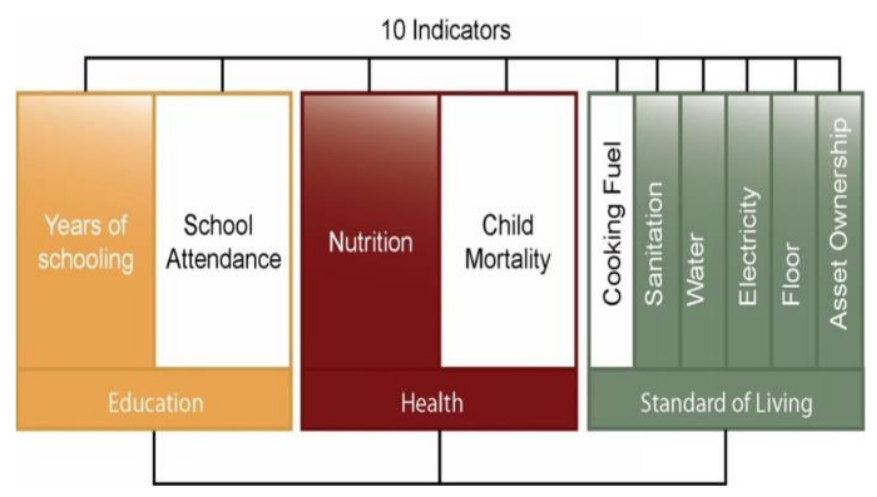

Diadopsi dari: Setyo Budiantoro, dkk (2014). 
Berdasarkan model-model/teori tersebut di atas, maka bagi penulis model yang digunakan sebagai pengkajian untuk menganalisis kemiskinan multidimensional yang ada di Kampung Aimo, Kelurahan Klamalu, Kabupaten Sorong, adalah model Multidimntional Poverty Index (MPI), dengan penjelasannya sebagai berikut:

\section{a. Kemiskinan Kesehatan}

Kamaluddin (1999) menjelaskan secara runtut bahwa, tingkat kesehatan yang rendah ini dapat diukur dengan masalah kekurangan gizi. Akibatnya, penyakit dengan muda menyerang penduduk miskin karena kurang gizi. Hal ini ditandai dengan angka harapan hidup yang semakin rendah, dimana saat ini rata-rata umur bagi Negaranegara berkembang adalah mendekati 50 dan rata-rata 73 tahun bagi Negara maju. Sedangkan tingkat kematian bayi sebelum umur 1 tahun per 1.000 penduduk adalah rata-rata 96 di Negara-negara berkembang, dan 15 di Negara maju.

Selain karena kekurangan gizi (malnutrisi), maka komponen rendahnya tingkat kesehatan dan tingginya angka kematian di Negara berkembang adalah masalah ketersediaan air bersih dan sanitasi lingkungan yang serba kekurangan di negara berkembang sehingga menimbulkan berbagai penyakit seperti diare, tifus, kolera, disentri, dan sebagainya yang banyak mengakibatkan kematian. Demikian pula terbatasnya dan buruknya fasilitas dan pelayanan kesehatan di Negara berkembang tersebut juga banyak menjadi penyebab tingginya angka kesakitan dan angka kematian.

Selain karena kekurangan gizi (malnutrisi), maka komponen rendahnya tingkat kesehatan dan tingginya angka kematian di Negara berkembang adalah masalah ketersediaan air bersih dan sanitasi lingkungan yang serba kekurangan di negara berkembang sehingga menimbulkan berbagai penyakit seperti diare, tifus, kolera, disentri, dan sebagainya yang banyak mengakibatkan kematian. Demikian pula terbatasnya dan buruknya fasilitas dan pelayanan kesehatan di Negara berkembang tersebut juga banyak menjadi penyebab tingginya angka kesakitan dan angka kematian.

Berdasarkan uraian diatas, maka untuk mengukur masalah kemiskinan dibidang kesehatan di lapangan/lokasi penelitian adalah meliputi 2 (dua) indikator, yaitu: a) Ada paling sedikit 1 anggota keluarga yang gizi buruk, dan b) Anggota keluarga meninggal(child mortality) karena gizi buruk.

\section{b. Kemiskinan Pendidikan}

Kemiskinan dibidang pendidikan, sangat ditentukan oleh beberapa permasalahan. (Kamaluddin, 1999) Mengatakan bahwa mengenai tingkat pendidikan yang rendah dapat dikemukakan hal-hal sebagai berikut: Pertama, rendahnya penyediaan dan penyebaran kesempatan memperoleh pendidikan merupakan penyebab yang penting atas rendahnya pendapatan dan tingkat penghidupan di Negara berkembang. Kedua, prioritas utama dalam pembangunan pendidikan di Negara berkembang adalah dalam penyediaan fasilitas pendidikan dasar, karena sebagian besar atau masih sangat banyak diantara penduduknya belum memperoleh pendidikan dasar dan yang melek huruf di kalangan masyarakat. Ketiga, sehubungan dengan itu, dikebanyakan Negara berkembang anggaran pengeluaran pemerintah yang dialokasikan ke sector pendidikan khususnya pendidikan dasar merupakan salah satu jumlah anggaran yang terbesar. Dan keempat, namun demikian sistem pendidikan termasuk pendidikan dasar di kebanyakan negara berkembang seringkali tidak cocok dan relevan dengan keperluan pembangunan suatu negara.upaya untuk mengatasinya dapat dilihat dalam strategi link and match dalam pendidikan di Indonesia.

Dengan demikian, tingkat pendidikan selalu berhubungan langsung dengan kemampuan ekonomi dari masyarakat miskin dipergunakan selaku dasar perkiraan kebutuhan minimum, tentu timbul kesukaran di dalam memperkirakan besarnya biaya yang harus dikeluarkan untuk mencapai tingkat pendidikan minimum tersebut (Ras, 2013). Namun, 
secara umum dan fakta di lapangan (khususnya di Negara-negara Sedang Berkembang/miskin maka kemiskinan dibidang pendidikan dapat ditinjau (diukur) dari menjadi 2 (dua) indikator untuk diteliti di lokasi penelitian, yaitu: a) Ada anggota keluarga yang tidak tamat Sekolah Dasar (SD), dan b) Ada anak usia dini yang tidak bersekolah.

\section{c. Kemiskinan Standar Hidup}

Pada umumnya di Negara-negara Sedang Berkembang, kemiskinan selalu menjadi bagian yang tak terelakkan dalam tatanan kehidupan masyarakat, terutama masyarakat yang hidup di pedesaan. Dimana, (Todaro, 1995) tingkat atau taraf kehidupan cenderung sangat rendah untuk sebagian besar penduduknya. Taraf kehidupan kehidupan yang rendah itu secara kualitatif maupun kuantitatif dijabarkan dalam bentuk pendapatan masyarakat yang rendah (kemiskinan), lingkungan hunian yang kurang memadai, penerangan listrik yang belum ada, tidak ada sumber air bersih, tidak ada MCK, memasak dengan kayu atau kotoran hewan, dan tidak memiliki kendaraan dan harta berharga.

Kriteria kebutuhan perumahan tidaklah begitu mudah dilakukan. Hal ini tentu dipengaruhi pula oleh jumlah anggota rumah tangga dan faktor-faktor lingkungan lainnya. Sedangkan mengenai kebutuhan papan cukup hanya diperhitungkan kebutuhan satu rumah untuk satu keluarga (Beik dkk, 2015). Berkaitan dengan itu, maka indikator-indikator yang dijadikan untuk mengukur kemiskinan standar hidup dilapangan, terdir dari: a) Tidak ada listrik, b) tidak ada sumber air bersih, c) Tidak ada MCK, d) Lantai rumah dari tanah, e) Memasak dengan kayu atau kotoran hewan (bukan BBM, atau listrik), f) tidak memiliki kendaraan (sepeda, kendaraaan bermotor, atau mobil), dan harta berharga (radio, telpon/HP, emas, kulkas).

\subsection{Hasil Penelitian Terdahulu}

Implementasi program pengadaan beras Miskin (Raskin) Di Kelurahan Paniki Kecamatan Siau Barat Kabupaten Kepulauan Siau Tagulandang Biaro
(Desmiati Arisandi Jacobus, 2015). Hasil penelitian menunjukkan bahwa Program Beras Raskin di Kelurahan Paniki belum dapat dikatakan berjalan dengan baik. Disebabkan oleh Indikator 6T yang merupakan indikator pengukur keberhasilan raskin belum terlaksana dengan tepat.

Studi implementasi program Beras Miskin (raskin) Di Wilayah Kelurahan Gajahmungkur Kecamatan Gajahmungkur Kota Semarang (Maryam Musawa, 2009). Hasil penelitian menunjukkan bahwa waktu yang terbatas pada saat tahap perencanaan menyebabkan program pelaksanaan Raskin terkesan "dipaksakan”. Keterbatasan waktu tersebut turut mempengaruhi keberhasilan pelaksanaan masing-masing tahapan dan keseluruhan program. Dalam pentargetan ditemui adanya kesalahan sasaran (mistargeting) meskipun dalam tingkat yang relatif rendah. Hal ini terindikasi dari adanya rumah tangga tidak miskin yang menjadi penerima Raskin (leakage) dan adanya rumah tangga miskin yang belum menjadi penerima (undercoverage).

Pemberdayaan Masyarakat Sebagai Upaya Pengentasan Kemiskinan di Provinsi Sulawesi Barat (Atma Ras, 2013). Temuan penelitian menunjukkan bahwa faktor perbedaan antarprogram, ketepatan program dengan kebutuhan masyarakat sasaran, keakuratan data calon penerima program, biaya manajemen, mekanisme penentuan target, kepraktisan organisasi, koordinasi antarlembaga, keberadaan lembaga-lembaga publik serta jumlah penerima manfaat program adalah faktorfaktor yang berperan sebagai pengungkit status keberlanjutan program pengentasan kemiskinan. Artinya jika di antara salah satu faktor-faktor ini dihilangkan maka akan berdampak pada status keberlanjutan program. Penelitian ini juga menunjukkan hasil evaluasi terhadap status keberlanjutan program pengentasan kemiskinan dan menyatakan bahwa program-program berbasis zakat adalah program dengan status keberlanjutan terbaik.

Evaluasi Program Pengentasan Kemisikinan Menggunakan Metode Rappoverty (Beik, 2015). Berbagai upaya yang dilakukan oleh pemerintah untuk menanggulangi kemiskinan, tetapi strategi 
yang dianggap paling tepat untuk mengurangi angka kemiskinan dengan melalui strategi pemberdayaan kepada masyarakat miskin. Melalui pemberdayaan, masyarakat dapat berpartisipasi mulai dari identifikasi kebutuhan, proses perencanaan, perumusan program sampai kepada evaluasi program yang bertujuan untuk meningkatkan kesejahteraan masyarakat, baik secara ekonomi, social, budaya dan politik.

Evaluasi Program-Program Pengentasan Kemiskinan Di Provinsi Bali (Mahaeni, 2014). Secara keseluruhan, efektivitas program bantuan di bidang pangan, khususnya bantuan Raskin lebih rendah dibandingkan dengan efektivitas kedua bantuan lainnya, yaitu pendidikan dan kesehatan. Ditinjau dari manfaat yangditerima, penerima bantuan di bidang pangan khususnya Bantuan Raskin, merasakan manfaat yang paling rendah. Kendala di lapangan pada saat bantuan belum didistribusikan seperti musyawarah desa/musyawarah kelurahan tidak dilakukan secara tepat waktu, sehingga data dari pusat yang diterima daerah yang digunakan sebagai dasar pendistribusian Raskin, menjadi kurang tepat.

Berdasarkan hasil dari berbagai penelitian tersebut diatas, pada umumnya berkesimpulan bahwa keberhasilan program bantuan Raskin belum dilaksanakan dengan baik oleh pelaksana teknis, karena tujuan semula dari program tersebut relatif belum efektif sesuai dengan syarat $6 \mathrm{~T}$ (tepat sasaran, jumlah, kualitas, harga, waktu, dan administrasi). Sehubungan dengan itu, maka perlu ada upaya untuk mendata kembali bagi penerima program bantuan Raskin sehingga yang menerima batuan benar-benar adalah masyarakat miskin.

Hasil penelitian ini bila dikaitkan dengan penelitian terdahulu, maka penelitian terdahulu lebih cenderung mengkaji dari aspek efektivitas penyaluran program bantuan Raskin yang meliputi 6 (enam) T, yaitu tepat sasaran, jumlah, harga, waktu, kualitas, administrasi. Artinya, penelitian terdahulu belum ada yang menganalisis program bantuan Raskin dari aspek ada/tidaknya pengaruh yang signifikan terhadap peningkatan kesejahteraan masyarakat miskin. Oleh karena itu, hasil dari penelitian ini dapat dijadikan sebagai bahan evaluasi untuk perencanaan program bantuan Raskin dilanjutkan (bila belum berhasil) dan/atau tidak (bila telah berhasil). Jika hasil penelitian ini, secara analisis kuantitatif belum menunjukkan keberhasilannya, maka diharapkan dengan adanya penelitian tersebut akan memberikan solusi yang sangat berguna untuk dapat dijadikan sebagai masukan dalam perencanaan program-program yang dianggap lebih tepat.

\section{METODE}

3.1 Lokasi Penelitian

Adapun lokasi penelitian ini berlangsung di Kampung Aimo, Kelurahan Mariat, Kabupaten Sorong, Provinsi Papua Barat. Alasan pemilihan lokasi penelitian karena masyarakat Kampung Aimo, telah cukup lama (lebih dari 10 Tahun) mendapatkan program bantuan Rastra. Dengan demikian perlu ada evaluasi program bantuan tersebut untuk dilanjutkan atau perlu ada perubahan kebijakan oleh pengambil kebijakan.

3.2 Populasi dan Sampel

Penelitian ini menggunakan metode survey terhadap populasi sebanyak 75 Kepala Kepala (KK). Jumlah sampel yang ditetapkan adalah 30 KK. Penetapan jumlah sampel tersebut dianggap telah mewakili populasi keseluruhan karena mempunyai ciri-ciri/karakteristik yang relatif homogen dan dilakukan secara acak.

\subsection{Sumber Data}

Data yang digunakan untuk keperluan analisis adalah data primer, yang terdiri dari survey/observasi (penelitian lapangan) dan wawancara.

a. Observasi

Adapun data yang dibutuhkan selama melakukan observasi di lokasi penelitian, meliputi: penerangan listrik, fisik bangunan tempat tinggal (permanen atau tidak), kepemilikan kendaraan (sepeda motor, dan mobil), kondisi lantai (tanah, lantai semen, dan tehel), ketersediaan air bersih, bahan memasak (BBM, kayu bakar), harta 
berharga (televisi, kulkas, emas, radio), ketersediaan MCK.

b. Wawancara

Ada pun data yang di peroleh melalui wawancara di lapangan, adalah sebagai berikut: tingkat pendidikan (tidak sekolah dan putus sekolah), asupan gisi (ada yang gisi buruk dan meninggal karena kekurangan gisi), penerima bantuan Raskin bagi Rumah Tangga Miskin (RTM) dilakukan, kualitas beras, program bantuan Raskin (dapat meningkatkan kesejahteraan atau belum) perlu program bantuan lainnya.

\subsection{Metode dan Teknik Analisis Data}

Penelitian ini menggunakan metode kuantitatif, sedangkan teknik analisis data dalam penelitian tersebut adalah menggunakan Indeks Kemiskinan Multidimensi atau MPI (Multidimensional Poverty Index). MPI adalah ukuran yang menunjukkan tingkat kemiskinan suatu Negara/daerah. Indeks ini merupakan suatu pendekatan baru yang dipakai oleh PBB untuk mengukur kemiskinan, dan mulai dipakai sejak tahun 2010.

Indeks terdiri atas tiga dimensi dan sepuluh indikator (variabel). Tiga dimensi itu adalah meliputi:

\section{Dimensi Kesehatan}

Adapun dimensi kesehatan yang akan diukur dilapangan, terdiri dari 2 (dua) indikator, yaitu: ada paling sedikit anggota keluarga yang menderita gisi buruk, ada anggota keluarga meninggal karena gisi buruk.

2. Dimensi Pendidikan

Dimensi pendidikan ini terdiri dari 2 (dua) indikator yang akan diukur di lapangan, yaitu: ada anggota keluarga yang tidak tamat SD, ada usia dini yang tidak bersekolah.

3. Dimensi Standar Hidup

Sedangkan untuk mengukur kemiskinan dibidang standar hidup, ada 6 (enam) indikator yaitu: tidak ada listrik, tidak ada sumber air bersih, tidak ada MCK, lantai rumah dari tanah, memasak dengan kayu atau kotoran hewan (bukan BBM, atau listrik), tidak memiliki kendaraan (sepeda, kendaraaan bermotor, atau mobil), dan harta berharga (radio, telpon/HP, emas, kulkas).

Kategori miskin ditentukan oleh berapa banyak variabel/indikator yang terdefrivasi (c). Angka defrivasi $c$ diperoleh dari jumlah hasil kali antara skor dan penimbang (pembobot). Skor diberikan kepada setiap jawaban rumah tangga yang diidentifikasi. Skor jawaban hanya 2 (dua) kemungkinan, 0 untuk jawaban tidak dan 1 untuk jawaban ya.

Berdasarkan hasil olahan data primer, baik yang diobservasi/survei langsung maupun melalui wawancara tertutup, maka dapatlah diambil kesimpulan/keputusan sebagai berikut:
a. Miskin, jika $c \geq 3$
b. Berisiko jadi miskin, jika $c=2-<3$
c. Tidak miskin, jika $c<2$

\section{HASIL}

4.1 Pengolahan Data

Berdasarkan hasil survei terhadap 30 sampel dari 75 populasi yang ada di Kampung Aimo, Kelurahan Klamalu, Kecamatan Mariat, Kabupaten Sorong, maka untuk memperoleh data di lokasi penelitian didasarkan pada Multidimentional Poverty Index (MPI), meliputi:

a. Kemiskinan Kesehatan

Adapun data yang diperoleh melalui survei terhadap dimensi kemiskinan kesehatan disini meliputi 2 (dua) dimensi, yaitu indikator: a) Ada paling sedikit 1 anggota keluarga yang gizi buruk, dan b) Anggota keluarga meninggal karena gizi buruk.

b. Kemiskinan Pendidikan

Untuk memperoleh data mengenai dimensi kemiskinan kesehatan, maka survei dilakukan pada 2 indikatori yang meliputi: a) Ada anggota keluarga yang tidak tamat Sekolah Dasar (SD), dan b) Ada anak usia dini yang tidak bersekolah.

c. Kemiskinan Standar Hidup

Didalam memperoleh data untuk dimensi kemiskinan standar hidup, maka indikator-indikator yang disurvei adalah: a) Tidak ada listrik, b) tidak ada sumber air bersih, c) Tidak ada MCK, d) Lantai rumah dari tanah, e) Memasak dengan kayu atau kotoran hewan (bukan BBM, atau listrik), f) tidak memiliki kendaraan (sepeda, kendaraaan bermotor, atau mobil), dan harta berharga (radio, telpon/HP, emas, kulkas). 
Adapun hasil tabulasi data, dapat dilihat pada lampiran penulisan penelitian tersebut (lampiran 1).

4.2 Hasil Penelitian

Berdasarkan hasil pengolahan data dengan menggunakan alat analisis Multidimentional Poverty Index (MPI), maka diperoleh angka defrivative $c \geq 3$ (lampiran 2). Bila hasil tersebut, dikonsultasikan dengan $M P I$ - nya berada diatas angka defrivative $c \geq 3$, berarti masyarakat di Kampung Aimo masuk dalam kategori miskin (Miskin, jika $c \geq$ 3). Hasil ini menunjukkan bahwa dengan adanya program bantuan Raskin di Kampung Aimo, ternyata belum bisa mengangkat masyarakat dari kemiskinan menjadi tidak miskin.

Berdasarkan dari beberapa hasil wawancara diatas maka dapat dikatakan bahwa program bantuan Raskin selama ini tidak tepat sasaran dan kualitas bantuan Raskin belum menunjukkan hasil yang baik untuk membantu masyarakat agar hidup yang layak. Karena itu, Pertama: bantuan Raskin yang tidak tepat sasaran maka perlu peninjauan ulang dalam pendataan namanama yang layak untuk menerima bantuan Raskin. Kedua: kualitas beras untuk Raskin harus yang layak konsumsi, sehingga penerima bantuan Raskin bersedia untuk mengkonsumsi. Ketiga, program bantuan Raskin yang diberikan kepada masyarakat di Kampung Aimo belum mampu membantu masyarakat miskin untuk hidup yang layak. Karena itu, untuk meningkatkan kesejahteraan masyarakat di Kampung Aimo maka perlu variasi kebijakan yang lain yakni kebijakan Raskin harus dilakukan secara bersamaan dengan program lain yang bertujuan mengentaskan kemiskinan. Misalnya: Kartu Sehat, Kartu Pintar dan upaya pemberdayaan masyarakat melalui program yang mandiri.

\section{KESIMPULAN}

Berdasarkan hasil penelitian, maka dapat disimpulkan bahwa Indeks Kemiskinan Multidimensional (Multidimensional Poverty Index/ $M P I$ ) yang meliputi 3 (Tiga) dimensi adalah kesehatan, pendidikan, dan standar hidup, Ternyata dengan adanya program bantuan beras sejahtera (Rastra) selama ini belum mampu meningkatkan kesejahteraan masyarakat di Desa Aimo Distrik Mariat Kabupaten Sorong Provinsi Papua Barat.

\section{DAFTAR PUSTAKA}

Beik, Irfan Syauqi, dkk (2015), Evaluasi Program Pengentasan Kemisikinan Menggunakan Metode Rappoverty, Institut Pertanian Bogor, Bogor.

Budiantoro, Setyo (2014), Konsep dan Pengukurannya Di Indonesia, Prakarsa Economic Policy Working Paper, Jakarta.

Hadna, Agus H (2016), Collaborative Governance dan Penurun Kemiskinan, Center for Population and Policy Studies Gadjah Mada University, UGM, Yogyakarta.

Kamaluddin, Rustian (1999), Pengatar Ekonomi Pembangunan, Analisis Beberapa Aspek Kebijakan pembangunan Nasional, FEUI, Jakarta.

Korten, David (1988), Pembangunan Berdimensi Kerakyatan, Yayasan Obor Indonesia, Jakarta.

Mahaeni, Aain dkk (2014), Evaluasi ProgramProgram Pengentasan Kemiskinan Di Provinsi Bali, Jurnal Piramida: Kependudukan \& Pengembangan Sumberdaya Manusia, Bali.

Nurlambang, Triarko (2014), Materi Kuliah: Konsep dan Teknik Perencanaan Daerah, Universitas Indonesia, Jakarta.

Panjaya, Yossy Herma (2011), Evaluasi Pelaksanaan Program Raskin Di Kota Semarang (Studi Kasus Kelurahan Pedurungan Kidul, FEUndip, Semarang.

Ras, Atma (2013), Pemberdayaan Masyarakat Sebagai Upaya Pengentasan Kemiskinan, Unhas, Makassar.

Remi, Sutyastie Soemitro dan Prijono Tjiptoherijanto (2002), Kemiskinan dan Ketidakmerataan di Indonesia, Rineka Cipta, Jakarta.

Sen, Amartya, (1981), Poverty and Famies: an Assay on Entitlement and Deprivation, Clarendom Press, Oxford.

.........., (2000), Development as Freedom, Oxford University Press, New Delhi.

Subarsono, AG (2009), Analisis Kebijakan Publik: Konsep, Teori, dan Aplikasi, Pustaka Pelajar, Yogyakarta. 
Sumodiningrat, Gunawan (1999), Pembangunan Masyarakat dan JPS, PT. Gramedia Pustaka Utama, Jakarta.

Todaro, Michael P (1995), Ekonomi Untuk Negara Berkembang: Suatu Pengantar Tentang Prinsip-prinsip, Masalah dan Kebijakan Pembangunan, Bumi Aksara, Jakarta.

Widodo, Tri (2006), Perencanaan Pembangunan: Aplikasi Komputer Era Otonomi Daerah, UPP STIM YKPN, Yogyakarta.

Panjaya, Yossy Herma (2011), Evaluasi Pelaksanaa Program Raskin Di Kota Sempung: Studi Kasus Kelurahan Pedurungan Kidul, FE Universitas Diponegoro, Semarang.

Yulianto, Trimo (2005), Fenomena ProgramProgram Pengentasan Kemiskinan di Kabupaten Klaten, Thesis, Program Pasca Sarjana, Magister Teknik Pembangunan Wilayah dan Kota, Universitas Diponegoro Semarang.

UU No. 7 Tahun 1996 Tentang Pangan.

Peraturan Pemerintah No. 68 Tahun 2002 Tentang Ketahanan Pangan.

Peraturan Presiden RI No. 54 Tahun 2005 Tentang Tim Koordinasi Penanggulangan Kemiskinan.

BPS, (2012), Produk Domestik Bruto, Jakarta.

Peraturan Presiden Republik Indonesia Nomor 15 tahun 2010 Tentang Percepatan Penanggulangan Kemiskinan.

Instruksi Presiden Nomor 3 tahun 2010 Tentang Program Pembangunan yang Berkeadilan.

Surat Keputusan Bersama dengan Mentri Dalam Negeri dengan Direktur utama Perum Bulog No. 25/2003 dan Nomor PKK $-12 / 07 / 2003$.

https://ac.uk.download/pdf/11704676.pdf ww.digilib.itb.ac.id 


\section{Lampiran 1}

Tabel: Hasil Survei Terhadap 30 Kepala Keluarga (KK)

\begin{tabular}{|c|c|c|c|c|c|c|c|c|c|c|c|c|c|c|c|c|c|c|c|c|c|c|c|c|c|c|c|c|c|c|}
\hline No Pengamatan Rumah Tangga & 1 & 2 & 3 & 4 & 5 & 6 & 7 & 8 & 9 & 10 & 11 & 12 & 13 & 14 & 15 & 16 & 17 & 18 & 19 & 20 & 21 & 22 & 23 & 24 & 25 & 26 & 27 & 28 & 29 & 30 \\
\hline Ukuran Keluarga(orang) & 6 & 5 & 4 & 9 & 6 & 5 & 7 & 6 & 4 & 3 & 7 & 6 & 8 & 6 & 6 & 4 & 6 & 7 & 5 & 6 & 6 & 3 & 7 & 5 & 4 & 8 & 4 & 6 & 5 & 3 \\
\hline \multicolumn{31}{|l|}{ Variabel Indikator: } \\
\hline $\begin{array}{l}\text { Ada paling sedikit anggota keluarga yang gizi } \\
\text { buruk }\end{array}$ & 0 & 0 & 0 & 1 & 0 & 0 & 0 & 0 & 0 & 1 & 0 & 0 & 0 & 0 & 0 & 0 & 0 & 0 & 0 & 0 & 0 & 0 & 1 & 0 & 0 & 0 & 0 & 0 & 0 & 0 \\
\hline $\begin{array}{l}\text { Ada Anggota keluarga yang Meninggal } \\
\text { karena gizi buruk }\end{array}$ & 0 & 0 & 0 & 0 & 0 & 0 & 1 & 0 & 0 & 0 & 0 & 0 & 0 & 0 & 0 & 1 & 0 & 0 & 0 & 0 & 0 & 0 & 0 & 0 & 0 & 0 & 0 & 0 & 0 & 0 \\
\hline Ada kelurga yang tidak tamat SD & 1 & 0 & 1 & 0 & 1 & 0 & 0 & 1 & 1 & 0 & 0 & 1 & 0 & 1 & 0 & 0 & 0 & 0 & 0 & 0 & 1 & 0 & 0 & 0 & 0 & 0 & 1 & 0 & 0 & 0 \\
\hline Ada anak usia sekolah yang tidak bersekolah & 0 & 1 & 0 & 1 & 0 & 1 & 1 & 0 & 0 & 0 & 1 & 0 & 1 & 0 & 0 & 0 & 1 & 0 & 0 & 0 & 1 & 0 & 1 & 0 & 0 & 0 & 0 & 0 & 1 & 0 \\
\hline Tidak ada listrik & 1 & 1 & 1 & 1 & 0 & 1 & 1 & 1 & 0 & 1 & 1 & 0 & 1 & 1 & 1 & 1 & 1 & 1 & 1 & 1 & 1 & 1 & 1 & 1 & 1 & 1 & 0 & 1 & 1 & 0 \\
\hline Tidak ada sumber air bersih & 1 & 1 & 1 & 1 & 0 & 1 & 1 & 0 & 1 & 1 & 1 & 1 & 1 & 1 & 0 & 1 & 1 & 1 & 1 & 1 & 1 & 1 & 1 & 1 & 0 & 1 & 1 & 0 & 0 & 0 \\
\hline Tidak ada MCK & 0 & 1 & 1 & 1 & 0 & 1 & 1 & 1 & 1 & 0 & 1 & 1 & 1 & 1 & 1 & 1 & 1 & 1 & 1 & 1 & 1 & 1 & 1 & 1 & 1 & 1 & 0 & 1 & 1 & 0 \\
\hline Lantai Rumah dari tanah & 1 & 0 & 1 & 1 & 0 & 0 & 1 & 1 & 1 & 0 & 1 & 1 & 0 & 1 & 1 & 1 & 0 & 1 & 0 & 0 & 1 & 1 & 1 & 1 & 0 & 1 & 1 & 1 & 1 & 0 \\
\hline $\begin{array}{l}\text { Memasak dengan kayu atau kotoran hewan } \\
\text { (bukan BBM atau listrik) }\end{array}$ & 0 & 1 & 1 & 1 & 0 & 1 & 1 & 1 & 1 & 1 & 1 & 1 & 1 & 1 & 1 & 1 & 1 & 0 & 1 & 1 & 1 & 0 & 0 & 0 & 0 & 0 & 0 & 0 & 1 & 0 \\
\hline $\begin{array}{l}\text { Tidak memiliki kendaraan (sepeda motor, } \\
\text { atau mobil) dan harta berharga (radio, TV, } \\
\text { Telp/HP, emas, kulkas) }\end{array}$ & 0 & 0 & 0 & 0 & 0 & 0 & 0 & 0 & 0 & 0 & 0 & 0 & 0 & 0 & 0 & 0 & 0 & 0 & 0 & 0 & 0 & 0 & 0 & 0 & 0 & 0 & 0 & 0 & 0 & 1 \\
\hline
\end{tabular}

\section{Sumber: Hasil Survei data Primer (2016)}




\section{Lampiran 2}

Tabel: Hasil Olahan Data Berdasarkan Analisis Multidimentional Poverty Index (MPI)

\begin{tabular}{|c|c|c|c|c|c|c|c|c|c|c|c|c|c|c|c|c|c|c|c|c|c|c|c|c|c|c|c|c|c|c|c|}
\hline No Pengamatan Rumah Tangga & 1 & 2 & 3 & 4 & 5 & 6 & 7 & 8 & 9 & 10 & 11 & 12 & 13 & 14 & 15 & 16 & 17 & 18 & 19 & 20 & 21 & 22 & 23 & 24 & 25 & 26 & 27 & 28 & 29 & 30 & $\begin{array}{c}\text { Penim- } \\
\text { bang }\end{array}$ \\
\hline Ukuran Keluarga(orang) & 6 & 5 & 4 & 9 & 6 & 5 & 7 & 6 & 4 & 3 & 7 & 6 & 8 & 6 & 6 & 4 & 6 & 7 & 5 & 6 & 6 & 3 & 7 & 5 & 4 & 8 & 4 & 6 & 5 & 3 & \\
\hline \multicolumn{32}{|l|}{ Variabel Indikator: } \\
\hline $\begin{array}{l}\text { Ada paling sedikit anggota keluarga } \\
\text { yang gisi buruk }\end{array}$ & 0 & 0 & 0 & 1.7 & 0 & 0 & 0 & 0 & 0 & 1.7 & 0 & 0 & 0 & 0 & 0 & 0 & 0 & 0 & 0 & 0 & 0 & 0 & 1.7 & 0 & 0 & 0 & 0 & 0 & 0 & 0 & $5 / 3$ \\
\hline $\begin{array}{l}\text { Ada Anggota keluarga yang } \\
\text { Meninggal karena gizi buruk }\end{array}$ & 0 & 0 & 0 & 0 & 0 & 0 & 1.7 & 0 & 0 & 0 & 0 & 0 & 0 & 0 & 0 & 1.7 & 0 & 0 & 0 & 0 & 0 & 0 & 0 & 0 & 0 & 0 & 0 & 0 & 0 & 0 & $5 / 3$ \\
\hline Ada kelurga yang tidak tamat SD & 1.7 & 0 & 1.7 & 0 & 1.7 & 0 & 0 & 1.7 & 1.7 & 0 & 0 & 1.7 & 0 & 1.7 & 0 & 0 & 0 & 0 & 0 & 0 & 1.7 & 0 & 0 & 0 & 0 & 0 & 1.7 & 0 & 0 & 0 & $5 / 3$ \\
\hline $\begin{array}{l}\text { Ada anak usia sekolah yang tidak } \\
\text { bersekolah }\end{array}$ & 0 & 1.7 & 0 & 1.7 & 0 & 1.7 & 1.7 & 0 & 0 & 0 & 1.7 & 0 & 1.7 & 0 & 0 & 0 & 1.7 & 0 & 0 & 0 & 1.7 & 0 & 1.7 & 0 & 0 & 0 & 0 & 0 & 1.7 & 0 & $5 / 3$ \\
\hline Tidak ada listrik & 0.6 & 0.6 & 0.6 & 0.6 & 0 & 0.6 & 0.6 & 0.6 & 0 & 0.6 & 0.6 & 0 & 0.6 & 0.6 & 0.6 & 0.6 & 0.6 & 0.6 & 0.6 & 0.6 & 0.6 & 0.6 & 0.6 & 0.6 & 0.6 & 0.6 & 0 & 0.6 & 0.6 & 0 & $5 / 9$ \\
\hline Tidak ada sumber air bersih & 0.6 & 0.6 & 0.6 & 0.6 & 0 & 0.6 & 0.6 & 0 & 0.6 & 0.6 & 0.6 & 0.6 & 0.6 & 0.6 & 0 & 0.6 & 0.6 & 0.6 & 0.6 & 0.6 & 0.6 & 0.6 & 0.6 & 0.6 & 0 & 0.6 & 0.6 & 0 & 0 & 0 & $5 / 9$ \\
\hline Tidak ada MCK & 0 & 0.6 & 0.6 & 0.6 & 0 & 0.6 & 0.6 & 0.6 & 0.6 & 0 & 0.6 & 0.6 & 0.6 & 0.6 & 0.6 & 0.6 & 0.6 & 0.6 & 0.6 & 0.6 & 0.6 & 0.6 & 0.6 & 0.6 & 0.6 & 0.6 & 0 & 0.6 & 0.6 & 0 & $5 / 9$ \\
\hline Lantai Rumah dari tanah & 0.6 & 0 & 0.6 & 0.6 & 0 & 0 & 0.6 & 0.6 & 0.6 & 0 & 0.6 & 0.6 & 0 & 0.6 & 0.6 & 0.6 & 0 & 0.6 & 0 & 0 & 0.6 & 0.6 & 0.6 & 0.6 & 0 & 0.6 & 0.6 & 0.6 & 0.6 & 0 & $5 / 9$ \\
\hline $\begin{array}{l}\text { Memasak dengan kayu atau kotoran } \\
\text { hewan (bukan BBM atau listrik) }\end{array}$ & 0 & 0.6 & 0.6 & 0.6 & 0 & 0.6 & 0.6 & 0.6 & 0.6 & 0.6 & 0.6 & 0.6 & 0.6 & 0.6 & 0.6 & 0.6 & 0.6 & 0 & 0.6 & 0.6 & 0.6 & 0 & 0 & 0 & 0 & 0 & 0 & 0 & 0.6 & 0 & $5 / 9$ \\
\hline $\begin{array}{l}\text { Tidak memiliki kendaraan (sepeda } \\
\text { motor, atau mobil) dan harta } \\
\text { berharga (radio, TV, Telp/HP, emas, } \\
\text { kulkas) }\end{array}$ & 0 & 0 & 0 & 0 & 0 & 0 & 0 & 0 & 0 & 0 & 0 & 0 & 0 & 0 & 0 & 0 & 0 & 0 & 0 & 0 & 0 & 0 & 0 & 0 & 0 & 0 & 0 & 0 & 0 & 0.6 & $5 / 9$ \\
\hline c (skor x penimbang) & 3.5 & 4.1 & 4.7 & 6.1 & 1.7 & 3.9 & 6.1 & 3.9 & 3.9 & 3.4 & 4.5 & 3.9 & 3.9 & 4.5 & 2.2 & 4.5 & 3.9 & 2.2 & 2.2 & 2.2 & 6.1 & 2.2 & 5.6 & 2.2 & 1.1 & 2.2 & 2.8 & 1.7 & 3.9 & 0.6 & \\
\hline c rata-rata & & & & & & & & & & & & & & & & 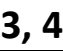 & & & & & & & & & & & & & & & \\
\hline
\end{tabular}

